\title{
INCUBATION OF JAPANESE QUAIL EGGS AT DIFFERENT TEMPERATURES: HATCHABILITY, HATCH WEIGHT, HATCH TIME AND EMBRYONIC MORTALITY
}

\author{
Incubação de ovos de codornas japonsesas em diferentes temperaturas: \\ eclodibilidade, tempo de nascimento, peso ao nascer e mortalidade embrionária
}

\author{
ROMAO, J.M. ${ }^{1}$; MORAES, T.G.V. ${ }^{2}$; TEIXEIRA, R.S.C. ${ }^{2}$; BUXADE, C.C. ${ }^{3}$; \\ CARDOSO, W.M. ${ }^{2}$
}

\author{
${ }^{1}$ Poultry Research Centre, University of Alberta. \\ ${ }^{2}$ Faculdade de Veterinária, Universidade Estadual do Ceará \\ ${ }^{3}$ Escuela Técnica Superior de Ingenieros Agrónomos, Universidad Politecnica de Madrid
}

Endereço para correspondência: Josue Moura Romao - romao@ualberta.ca

\begin{abstract}
Temperature is the most important factor affecting embryonic development, hatchability and post hatch performance. Optimum incubation temperature is normally defined as that required to achieve maximum hatchability. This work was carried out to verify the effects of different incubation temperatures on hatchability, hatch weight, hatch time and embryonic mortality of Japanese quail eggs. A total of 800 eggs were divided in eight experimental groups that were incubated at different temperatures $\left(34,35,36,37,38,39,40\right.$ and $\left.41^{\circ} \mathrm{C}\right)$. The other incubation conditions were identical for all groups, $60 \pm 5 \%$ of relative humidity and egg turning every two hours until transference to the hatchers at 15 days of incubation. The results showed that fertile hatchability was higher for eggs incubated at 37 and $38 \circ \mathrm{C}, 76.6$ and $80.7 \%$, respectively. Eggs incubated at $34^{\circ} \mathrm{C}$ did not hatch and the ones incubated at 35 and $41^{\circ} \mathrm{C}$ showed very poor hatchability. The other temperatures had hatch rates from 50.3 to $57.7 \%$. There were higher hatch weights in eggs incubated at high temperatures $\left(38-41^{\circ} \mathrm{C}\right)$ compared to the ones incubated at the lower ones $\left(35-37{ }^{\circ} \mathrm{C}\right)$. $\mathrm{T}^{\mathrm{T}}$ here was an enormous difference in the hatching time according to the incubation temperature. The difference of time between the groups of eggs that hatched earlier $\left(40^{\circ} \mathrm{C}\right)$ compared to the ones the hatcher later $\left(3^{\circ} \mathrm{C}\right)$ was 156.3 hou rs or 6.5 days. Embryos seemed to be resistant to at high temperatures until $40^{\circ} \mathrm{C}$ at the early period of incubation, ho wever the same was not observed at the later stages of incubation when high temperatures $\left(39-41^{\circ} \mathrm{C}\right)$ increased embryoni c mortality.
\end{abstract}

Key words: hatch performance; humidity; poultry; temperature

\section{RESUMO}

A temperatura é o fator mais importante para o desenvolvimento embrionário, a eclodibilidade e o desempenho pósnascimento de aves. A temperatura ideal é normalmente aquela que permite máxima eclodibilidade. Este trabalho verificou os efeitos de diferentes temperaturas de incubação sobre a eclodibilidade, perda de peso dos ovos, peso ao nascer, tempo de nascimento e mortalidade embrionária de ovos de codornas japonesas. Foram utilizados 800 ovos, divididos em oito grupos experimentais e incubados em diferentes temperaturas (34, 35, 36, 37, 38, 39, 40 e $41^{\circ} \mathrm{C}$ ). As demais condições de incubação foram idênticas para todos os grupos, $60 \pm 5 \%$ de umidade relativa e viragem a cada 2 horas até a transferência para a nascedoura no 15 dia de incubação. A eclodibilidade dos ovos férteis foi maior para os ovos incubados a 37 e $38^{\circ} \mathrm{C} ; 76,6$ e $80,7 \%$, respectivamente. Os ovos incubados a $34^{\circ} \mathrm{C}$ não eclodiram e os incubados a 35 e $41^{\circ} \mathrm{C}$ apresentaram um índice muito baixo de eclodibilidade. As outras temperaturas proporcionaram eclodibilidade entre 50,3 e $57,7 \%$. Os pesos ao nascer foram elevados nos grupos incubados em temperaturas altas $\left(38-41^{\circ} \mathrm{C}\right)$ quando comparados aos grupos incubados em temperaturas baixas $\left(35-37^{\circ} \mathrm{C}\right)$. Observou-se diferen ça no tempo de nascimento de acordo com a temperatura de incubação. A diferença de tempo entre o grupo de ovos que eclodiram mais cedo $\left(40^{\circ} \mathrm{C}\right)$ e os ovos que eclodiram por último $\left(3^{\circ} \mathrm{C}\right)$ foi de 156,3 horas ou 6,5 dias. Os embriões apresentaram-se resistentes a altas temperaturas até $40^{\circ} \mathrm{C}$ durante o período inicial da incubação, cont udo o mesmo não foi observado nos estágios finais de incubação, quando altas temperaturas $\left(39-41{ }^{\circ} \mathrm{C}\right)$ aumentaram a m ortalidade embrionária.

Palavras-chave: eclosão; poedeira; temperatura; umidade 


\section{INTRODUCTION}

The performance of artificial incubation in poultry species, including Japanese quails, can be affected by a series of factors, such as egg turning (Moraes et al., 2008), relative humidity (Romao et al., 2009), egg storage (Romao et al., 2008, 2010; Moraes et al., 2009), and others, however temperature is considered to be the most important factor affecting embryonic development (Romanoff, 1972), hatchability (Deeming and Ferguson, 1991) and post hatch performance (Wilson, 1991). Embryonic development and incubation period depends on the age of the embryo, duration of exposure as well as humidity, type of incubator and temperature (Wilson, 1991). During artificial incubation, the embryo temperature is dependent on incubator temperature, embryonic metabolic rate, and thermal conductance of the egg and surrounding air (French, 1997). Optimum incubation temperature is normally defined as that required to achieve maximum hatchability (French, 1997). However, Decuypere and Michels (1992) have argued that the quality of the hatchlings should also be considered.

The incubation process on domestic chicken can be performed under temperatures higher or lower than the one considered optimum for the specie $\left(37.5^{\circ} \mathrm{C}\right)$. However, changes in incubational temperature may alter the standard embryonic development with detrimental effects for hatchability (Alda, 1994). The major effects of incubation at temperatures outside the optimal range are increases in embryonic mortality, deformities and failure to hatch (Romanoff, 1960; Lundy, 1969).

There are several studies that observed the effect of temperature on length of incubation (Michels et al., 1974; French 1994, Suarez et al., 1996), on the rate of embryo growth (Decuypere et al., 1979; Dias and Muller, 1998), and on hatchability (Wilson, 1991; Lourens et al., 2005).
However, there are few studies about these effects on Japanese quail incubation performance.

This work was carried out to evaluate the effect of different incubation temperatures on hatchability, hatch weight, hatching time and embryo mortality of Japanese quail eggs.

\section{MATERIAL AND METHODS}

A total of 150 Japanese quails (Coturnix japonica) were used for egg collections. The birds were reared in experimental cages in the Laboratório de Estudos Ornitológicos- Universidade Estadual do Ceará. They were lodged at a ratio of two females and one male in each cage. Birds were 22 week old and averaged $90 \%$ of egg laying production. All quails were supplied with balanced feed, water ad libitum and exposed to 17 hours/day of light.

The eggs were selected for incubation verifying egg shape, extreme sizes and eggshell integrity by candling. They were divided into eight experimental groups according to incubation temperature. The eggs were incubated at $34^{\circ} \mathrm{C}(n=100)$, $35^{\circ} \mathrm{C} \quad(n=100), \quad 36^{\circ} \mathrm{C} \quad(n=100), \quad 37^{\circ} \mathrm{C}$ $(n=100), 38^{\circ} \mathrm{C}(\mathrm{n}=100), 3^{\circ} \mathrm{C}(\mathrm{n}=100)$, $40^{\circ} \mathrm{C}(n=100)$ and $41^{\circ} \mathrm{C}(\mathrm{n}=100)$ from day 0 to hatching. Each group of eggs was incubated in a separated incubator, according to its experimental incubation temperature. Incubation process was done by automatic incubators with relative humidity of $60 \pm 5 \%$ and egg turning every 2 hours. At the $15^{\text {th }}$ day of incubation (360h) egg turning was stopped and the eggs were transferred to the hatchers which maintained the same temperature and relative humidity until hatch.

All eggs were identified, individually, and weighed, by a precision balance $(0.001 \mathrm{~g})$, on the first day of incubation. After transfer at the hatchers, the eggs 
were monitored to verify their hatching time every six hours. All quail chicks were weighed individually after hatchling.

Eggs that failed to hatch were opened for macroscopically observation, thus they were classified according to time of embryonic mortality. They were staged as infertile, early death embryos (1 up to 4 days), intermediate (5 up to 15 days) and late death embryos (16 up to 18 days), according to Pedroso et al. (2006).

Each experimental group $(n=100)$ consisted of five replicates of 20 eggs. All data were analyzed using the Statistix software 8.0 (2003). The results were submitted the test of Shapiro-Wilk to verify normality and to Bartlett's test to verify homogeneity of variances. Hatchability, chick/egg weight and hatch time means were submitted to Analysis of Variance through general linear model and the means were compared with the test of Tukey. Embryonic mortality means were compared through Kruskal-Wallis' test. Statements of significance were based on $\mathrm{P}<0.05$.

\section{RESULTS}

Table 1 shows the total hatchability which consisted of hatch rate of all eggs incubated and the fertile hatchability which was obtained from incubated eggs excluding the infertile eggs.

Table 1 - Total and fertile hatchability of Japanese quail eggs incubated in different temperatures

\begin{tabular}{ccc}
\hline $\begin{array}{c}\text { Temperature } \\
\left({ }^{\circ} \mathrm{C}\right)\end{array}$ & $\begin{array}{c}\text { Total } \\
\text { hatchability } \\
\text { Mean } \pm \text { SD }(\%)\end{array}$ & $\begin{array}{c}\text { Fertile } \\
\text { hatchability } \\
\text { Mean } \pm \text { SD (\%) }\end{array}$ \\
\hline 34 & $0.00 \pm 0.00^{\mathrm{d}}$ & $0.00 \pm 0.00^{\mathrm{d}}$ \\
35 & $4.00 \pm 2.24^{\mathrm{cd}}$ & $4.36 \pm 2.48^{\mathrm{cd}}$ \\
36 & $48.00 \pm 7.58^{\mathrm{b}}$ & $54.63 \pm 8.37^{\mathrm{b}}$ \\
37 & $69.00 \pm 6.52^{\mathrm{a}}$ & $76.67 \pm 7.24^{\mathrm{a}}$ \\
38 & $75.00 \pm 6.12^{\mathrm{a}}$ & $80.76 \pm 7.75^{\mathrm{a}}$ \\
39 & $53.00 \pm 6.71^{\mathrm{b}}$ & $57.73 \pm 7.81^{\mathrm{b}}$ \\
40 & $46.00 \pm 7.42^{\mathrm{b}}$ & $50.33 \pm 5.35^{\mathrm{b}}$ \\
41 & $15.00 \pm 5.00^{\mathrm{c}}$ & $16.68 \pm 6.48^{\mathrm{c}}$ \\
\hline $\mathrm{a}, \mathrm{b}, \mathrm{c}, \mathrm{d}$
\end{tabular}

a,b,c,d Means within the columns with different superscripts differ significantly $(P<0.05)$.
The eggs incubated at $37^{\circ} \mathrm{C}$ and $38^{\circ} \mathrm{C}$ had the highest hatchabilities. They were followed by the eggs incubated at $36^{\circ} \mathrm{C}$, $39^{\circ} \mathrm{C}$ and $40^{\circ} \mathrm{C}$ that presented fertile hatch rates between $50.3 \%$ and $57.3 \%$. The lowest hatch rates were found for the eggs incubated at $35^{\circ} \mathrm{C}$ and $41^{\circ} \mathrm{C}$. It was verified that extremely high or low temperatures were very harmful for egg hatchability.

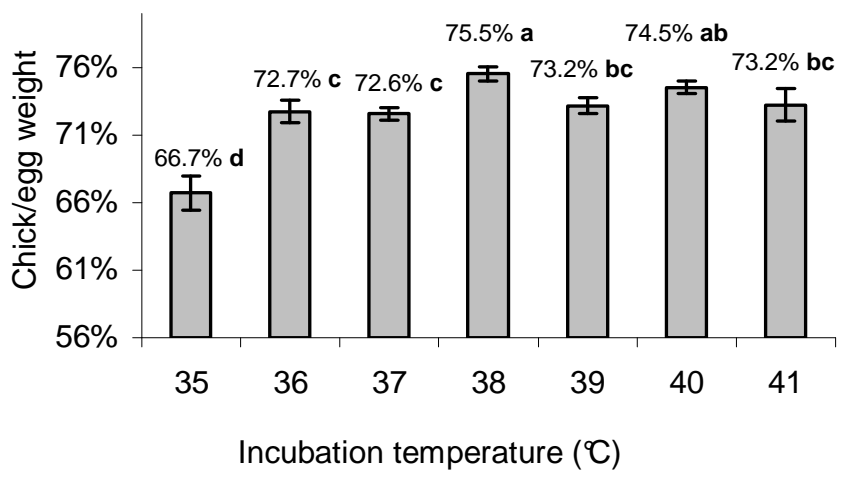

Figure 1 - Chick/egg weight ratio (\%) of Japanese quail eggs incubated in different temperatures.

a,b,c,d Means with different superscripts differ significantly $(P<0.05)$

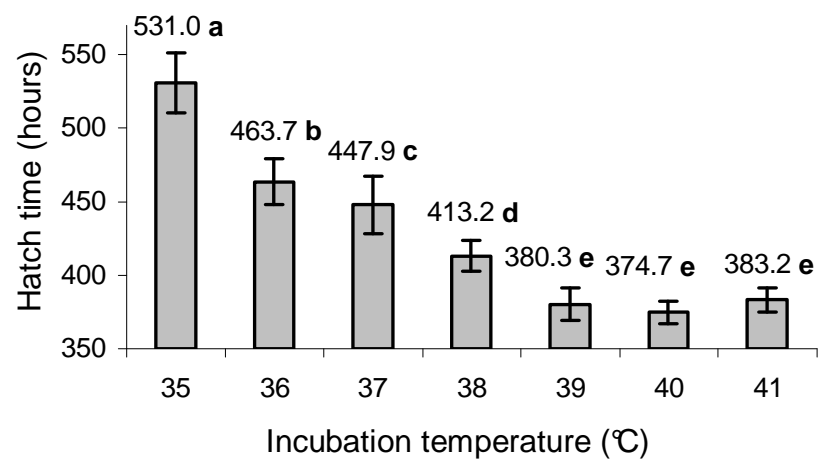

Figure 2 -Hatching time of Japanese quail eggs incubated at different temperatures.

a,b,c,d,e Means with different superscripts differ significantly $(P<0.05)$

The chick/egg weight of Japanese quail chicks varied between $66.7 \%$ to $75.5 \%$, showing that incubation temperature promoted a variation up to $13 \%$ of Japanese quail hatch weight. The highest proportional weights at hatch were observed for eggs incubated at the $38^{\circ} \mathrm{C}$, $39^{\circ} \mathrm{C} 40^{\circ} \mathrm{C}$ and $41^{\circ} \mathrm{C}$. Their means of hatch 
Table 2 - Classification of Japanese quail eggs that failed to hatch after incubation in different temperatures.

\begin{tabular}{ccccccc}
\hline $\begin{array}{c}\text { Temp. } \\
\left({ }^{\circ} \mathrm{C}\right)\end{array}$ & Infertile & Early death & $\begin{array}{c}\text { Intermediate } \\
\text { death }\end{array}$ & Late death & Pipped egg & Total \\
\hline \multicolumn{7}{c}{ Mean \pm SD (\%) } \\
\hline 34 & $11 \pm 4.18^{\mathrm{a}}$ & $35 \pm 12.75^{\mathrm{a}}$ & $36 \pm 10.84^{\mathrm{a}}$ & $18 \pm 4.47^{\mathrm{abc}}$ & $0 \pm 0.00^{\mathrm{b}}$ & $100.00^{\mathrm{a}}$ \\
35 & $10 \pm 9.35^{\mathrm{a}}$ & $13 \pm 4.47^{\mathrm{abc}}$ & $9 \pm 9.62^{\mathrm{ab}}$ & $38 \pm 10.37^{\mathrm{a}}$ & $24 \pm 8.94^{\mathrm{a}}$ & $94.00^{\mathrm{ab}}$ \\
36 & $12 \pm 5.70^{\mathrm{a}}$ & $1 \pm 2.24^{\mathrm{c}}$ & $5 \pm 7.07^{\mathrm{ab}}$ & $12 \pm 5.70^{\mathrm{abc}}$ & $22 \pm 9.75^{\mathrm{a}}$ & $52.00^{\mathrm{c}}$ \\
37 & $10 \pm 0.00^{\mathrm{a}}$ & $4 \pm 4.18^{\mathrm{bc}}$ & $1 \pm 2.24^{\mathrm{b}}$ & $6 \pm 6.52^{\mathrm{bc}}$ & $10 \pm 6.12^{\mathrm{ab}}$ & $31.00^{\mathrm{d}}$ \\
38 & $8 \pm 4.47^{\mathrm{a}}$ & $6 \pm 2.24^{\mathrm{abc}}$ & $0 \pm 0.00^{\mathrm{b}}$ & $3 \pm 4.47^{\mathrm{c}}$ & $8 \pm 4.47^{\mathrm{ab}}$ & $25.00^{\mathrm{d}}$ \\
39 & $8 \pm 4.47^{\mathrm{a}}$ & $6 \pm 4.18^{\mathrm{abc}}$ & $3 \pm 6.71^{\mathrm{ab}}$ & $15 \pm 10.61^{\mathrm{abc}}$ & $15 \pm 11.73^{\mathrm{ab}}$ & $47.00^{\mathrm{c}}$ \\
40 & $9 \pm 6.52^{\mathrm{a}}$ & $6 \pm 5.48^{\mathrm{abc}}$ & $1 \pm 2.24^{\mathrm{b}}$ & $19 \pm 8.94^{\mathrm{abc}}$ & $18 \pm 8.37^{\mathrm{a}}$ & $53.00^{\mathrm{c}}$ \\
41 & $8 \pm 7.58^{\mathrm{a}}$ & $29 \pm 10.84^{\mathrm{ab}}$ & $9 \pm 4.18^{\mathrm{ab}}$ & $31 \pm 11.94^{\mathrm{ab}}$ & $9 \pm 4.18^{\mathrm{ab}}$ & $86.00^{\mathrm{b}}$ \\
\hline $\mathrm{a}, \mathrm{b}, \mathrm{c}, \mathrm{d}$ & Means within the columns with different superscripts differ significantly $(\mathrm{P}<0.05)$ &
\end{tabular}

weight varied from $9.1 \mathrm{~g}$ to $9.6 \mathrm{~g}$. They were followed by eggs incubated at $36^{\circ} \mathrm{C}$ and $37^{\circ} \mathrm{C}, 8.7 \mathrm{~g}$ and $9.1 \mathrm{~g}$, respectively. The lowest weights at hatch were found in eggs incubated at $35^{\circ} \mathrm{C}$ that had a mean hatch weight of $8.4 \mathrm{~g}$. No chicks hatched when incubated at $34^{\circ} \mathrm{C}$. In general the higher incubation temperatures promoted heavier quail chicks than the lower ones.

There was a great difference in the hatching time according to the incubation temperature. The difference of time between the groups of eggs that hatched earlier $\left(40^{\circ} \mathrm{C}\right)$ compared to the one that hatched later $\left(3^{\circ} \mathrm{C}\right)$ was 156.3 hours or 6.51 days. The average hatch time ranged from 374.7 to 531.0 hours, which is the same of 15.61 and 22.12 days of incubation until hatch, respectively. The increase of incubation temperature from $35^{\circ} \mathrm{C}$ to $41^{\circ} \mathrm{C}$ reduced expressively the hatching time of Japanese quail eggs, however this effect was observed for incubation temperatures until $3^{\circ} \mathrm{C}$, since the hatching time of eggs incubated in higher temperatures were similar to that one. The eggs incubated at $34^{\circ} \mathrm{C}$ were followed up to 30 days of incubation to verify the hatching time, however they did not hatch and when they were opened (30d) the quail embryos were already dead.
The table 2 shows the classification of eggs that failed to hatch after incubation in different temperatures. The eggs were considered infertile, early embryo death, intermediate embryo death, late embryo death or pipped egg with dead embryo.

The rate of infertile eggs ranged from $8 \%$ to $12 \%$ of total eggs. This classification of unhatched egg is not dependant of incubation temperature, this way there was no statistical difference among groups. The early embryonic death was more critical for eggs incubated in extreme temperatures such as $34^{\circ} \mathrm{C}$ and $4^{\circ} \mathrm{C}$. The intermediate embryo death was higher in eggs incubated at $34^{\circ} \mathrm{C}$ and lower levels were found in the central temperatures (36 to $40^{\circ} \mathrm{C}$ ). The late embryonic death was lower in eggs incubated at 37 and $3^{\circ} \mathrm{C}$, while the other temperatures presented higher levels. Only eggs incubated at $34^{\circ} \mathrm{C}$ had no pipped eggs. In general, the eggs incubated at 37 and $38^{\circ} \mathrm{C}$ had lower levels of unhatched eggs while the other presented higher levels reaching $100 \%$ for eggs incubated at $34^{\circ} \mathrm{C}$.

\section{DISCUSSION}

Hatchability

The highest hatch rates were found for eggs incubated at $37^{\circ} \mathrm{C}$ and ${ }^{\circ} 8^{\circ} \mathrm{C}$ which is in accordance to the optimal temperature 
to the development of the chicken embryos that occurs within the narrow temperature range of 37 to $38^{\circ} \mathrm{C}$ (Romanoff, 1960). Pedroso et al. (2006) found similar fertile hatchability for Japanese quail eggs incubated at $36.5^{\circ} \mathrm{C}$ and $37.5^{\circ} \mathrm{C}$, that was $76.57 \%$ and $76.55 \%$, respectively. The eggs incubated at $34^{\circ} \mathrm{C}$ were not able to hatch, however these eggs presented quail embryos that developed up to final stages. The temperature of $35^{\circ} \mathrm{C}$ was detrimental for embryo survival promoting a poor hatchability $(4.36 \%)$. It has been reported that hypothermic incubation $\left(3^{\circ} \mathrm{C}\right)$ promotes a series of physiological dysfunctions in chicken embryos (Black and Burggren, 2004a,b). The incubation at $36^{\circ} \mathrm{C}$ presented much better hatch rate compared to $35^{\circ} \mathrm{C}$, however it was considerably lower than 37 and $38^{\circ} \mathrm{C}$. The temperatures above $3^{\circ} \mathrm{C}$ were also harmful to quail embryos decreasing the hatch rates. Incubation temperatures above the optimal have been reported to negatively impact hatchability, feed conversion, BW, and general post-hatch chick and poult performance (Gladys et al., 2000). However higher and lower than optimal incubation temperatures may not be considered completely detrimental to quail incubation since it can be used in an intermittent way throughout the incubation. Callebaut (1990) studied artificial incubation of Japanese quail eggs trying to mimic the natural incubation conditions with daily 8 hours interruptions (low temperatures) and he found that it was possible to lengthen the embryonic period by one-third without apparent harm and with potential improvement in hatchability.

\section{Hatch Weight}

The incubation temperature promoted a higher hatch weight in eggs incubated at high temperatures $\left(38-41^{\circ} \mathrm{C}\right)$ compared to the ones incubated at the lower ones (35$\left.3^{\circ} \mathrm{C}\right)$. In a general way the higher temperatures tended to increase the hatch weight. This was also observed by Pedroso et al. (2006), who found an increase chick/egg weight ratio from eggs incubated in a lower and in a higher temperature. However they found a higher difference which was $51.5 \%$ and $64.4 \%$ for $36.5^{\circ} \mathrm{C}$ and $37.5^{\circ} \mathrm{C}$, respectively. Hammond et al. (2007) verified that higher incubation temperatures of $38.5^{\circ} \mathrm{C}$ compared to $37.5^{\circ} \mathrm{C}$ increases not only the chick hatch weight but it also increases leg bones, more muscle fibers and nuclei in the gastrocnemius, more in ovo embryo motility during incubation and a reduction in adipose tissue. However much higher temperatures can be potentially detrimental to incubation of quail eggs, since Leksrisompong (2005) observed that chicken eggs incubated in temperatures from 39.5 to $40.6^{\circ} \mathrm{C}$ showed body weight, and weights of the heart, gizzard, proventriculus, and small intestines frequently reduced.

\section{Hatching Time}

The incubation time can be influenced by many factors like temperature (Suarez et al., 1996; Wilson, 1991), egg weight (Burton and Tullet, 1985), age of breeder (Smith and Bohren, 1975) and also preincubation storage (Bohren, 1978). Incubation temperatures above the optimal temperature have been reported to accelerate growth rates of avian embryos (Romanoff, 1960; Christensen et al., 1999). The incubation temperature highly influenced the hatching time of Japanese quail eggs. The lowest temperature that allowed embryo hatching was $3^{\circ} \mathrm{C}$. Compared to $38^{\circ} \mathrm{C}$ this temperature increased almost 5 days in the hatching time. Chicken eggs incubated in the same temperatures had a lower difference between the hatching times, which was 4 days (Tazawa et al., 1988). Pedroso et al. (2006) found similar hatching times for Japanese quail eggs; eggs incubated at $36.5^{\circ} \mathrm{C}$ and $37.5^{\circ} \mathrm{C}$ hatched after 442.5 and 413.6 hours, respectively. The change of incubation temperature for small periods can also influence the hatching time as reported by Leandro et al. (2000) who 
verified the effects of small period (5 hours) of heat $\left(400^{\circ} \mathrm{C}\right)$ or cold $\left(3^{\circ} \mathrm{C}\right)$ stress in chicken eggs incubated at $37.8^{\circ} \mathrm{C}$ and observed an increase of hatching time of around 10 and 8 hours, respectively.

Embryonic Mortality

Embryo mortality pattern of Japanese quail eggs was similar to the one observed in chickens, in which there are two phases of increased embryonic mortality during incubation: the first phase occurs during the first week of incubation and the second phase during the last week (Jassim et al., 1996). In general, all embryo mortality classifications tended to be lower for eggs incubated in the central temperatures (37' $\mathrm{C}$ and $\left.38^{\circ} \mathrm{C}\right)$. Embryos seemed to be resistant to embryo death in high temperatures of incubation until $40^{\circ} \mathrm{C}$ at the early period of incubation, however the same was not observed at the later stages of incubation when high incubation temperatures $\left(39-41{ }^{\circ} \mathrm{C}\right)$ promoted high levels of embryo mortality (late death and pipped eggs). These results are in accordance to Ono et al. (1994) that verified that chicken embryos are more susceptible to high temperatures in the end of incubation. Both extremes of high and low incubation temperatures may reduce hatchability due to the lack of a complete capacity to thermoregulate its own temperature since the embryos are poikilotherm until hatch.

\section{CONCLUSIONS}

The most suitable machine setting incubation temperatures for Japanese quail eggs were 37 and $38^{\circ} \mathrm{C}$, constantly. Higher and lower temperatures resulted in low hatch rates. In general, high incubation temperatures $\left(38,39,40\right.$ and $\left.41^{\circ} \mathrm{C}\right)$ increased hatch weight and decreased hatching time, while lower temperatures $\left(34,35,36\right.$ and $\left.37^{\circ} \mathrm{C}\right)$ resulted in the opposite.

\section{ACKNOWLEDGMENTS}

The authors gratefully thank FUNCAP and $\mathrm{CNPq}$ for their scholarship support to Romao J.M. and Moraes. T.G.V.

\section{REFERENCES}

ALDA, T.R.B.L. Causas de mortalidade embrionária e deformidades do embrião. In: PINHEIRO, M.R.

Manejo da incubação. São Paulo: FACTA, 1994. p.160-177.

BLACK, J.L.; BURGGREN, W.W. Acclimation to hypothermic incubation in developing chicken embryos (Gallus domesticus) I. Developmental effects and chronic and acute metabolic adjustments. The Journal of Experimental Biology, v.207, p.1543-1552, 2004a.

BLACK, J.L.; BURGGREN, W.W. Acclimation to hypothermic incubation in developing chicken embryos (Gallus domesticus) II. Hematology and blood $\mathrm{O} 2$ transport. The Journal of Experimental Biology, v.207, p.1553-1561, 2004b.

BOHREN, B.B. Preincubation storage effects on hatchability and hatching time of lines selected for fast and slow hatching. Poultry Science, v.57, p.581-583, 1978.

BURTON, F.G.; TULLET, S.G. The effect of egg weight and shell porosity on the growth and water balance of the chicken embryo. Comparative Biochemistry and Physiology, v.81, p.377-385, 1985.

CALLEBAUT, M.E. Hatching of Japanese quail chicks (Coturnix coturnix japonica) following long, daily cyclical interruptions of their incubation. Poultry Science, v.69, p.2241-2243, 1990.

CHRISTENSEN, V.L.; DONALDSON, W.E.; NESTOR, K.E. Length of plateau and pipping stages of incubation affects the physiology and survival of turkeys. British Poultry Science, v.40, p.297-303, 1999.

DECUYPERE, E.; MICHELS, H. Incubation temperature as a management tool: a review. World's Poultry Science Journal, v.48, p.28-38, 1992.

DECUYPERE, E.; NOUWEN, E.J.; KUHN, E.R. et al. lodohormones in the serum of chick embryos and post-hatching chickens as influence by incubation temperature. Relationship with the hatching process and thermogenesis. Annales de Biologie Animale, Biochimie, Biophysique, v.19, p.1713-1723, 1979. 
DEEMING, D.C.; FERGUSON, M.W.J.

Physiological effects of incubation temperature on embryonic development in reptiles and birds. In: DEEMING, D.C.; FERGUSON, M.W.J. Egg Incubation, Cambridge: Cambridge University Press, 1991, p.147-172.

DIAS, P.F.; MULLER, Y.M.R. Características do desenvolvimento embrionário de Gallus gallus domesticus, em temperaturas e períodos diferentes de incubação. Brazilian Journal of Veterinary Research and Animal Science, v.35, p.233-235, 1998.

FRENCH, N.A. Effect of incubation temperature on the gross pathology of turkey embryos. British Poultry Science, v.35, p.363-371, 1994.

FRENCH, N.A. Modeling incubation temperature: The effects of incubator design, embryonic development, and egg size. Poultry Science, v.76, p.124-133, 1997.

GLADYS, G.E.; HILL, D.; MEIJERHOF, R. et al. Effect of embryo temperature and age of breeder flock on broiler post hatch performance. Poultry Science, v.79 (Suppl. 1), 123 (abstract), 2000.

HAMMOND, C.L.; SIMBI, B.H.; STICKLAND, N.C. In ovo temperature manipulation influences embryonic motility and growth of limb tissues in the chick (Gallus gallus). The Journal of Experimental Biology, v.210, p.2667-2675, 2007.

JASSIM, E.W.; GROSSMAN, M.; KOPS, W.J. et al. Multiphasic analysis of embryonic mortality in chickens. Poultry Science, v.75, p.464-471, 1996.

LEANDRO, N.S.M.; GONZALES, E.; VAROLI, Jr.J.C.V. et al. Incubabilidade e Qualidade de Pintos de Ovos Matrizes de Frangos de Corte Submetidos a Estresse de Temperatura. Brazilian Journal of Poultry Science, v.2, p.39-44, 2000.

LEKSRISOMPONG, N. Effect of temperature during incubation and brooding on broiler chickens. 2005. Raleigh, 156p. Master's degree Thesis - Poultry Science, North Carolina State University.

LOURENS, A.; VAN DE BRAND, H.; MEIJERHOF, $R$. et al. Effect of eggshell temperature during incubation on embryo development, hatchability, and posthatch development. Poultry Science, v.84, p.914-920, 2005.

LUNDY, $\mathrm{H}$. A review of the effects of temperature, humidity, turning and gaseous environment in the incubator on the hatchability of the hen's egg. In: CARTER, T.C.; FREEMAN, B.M. The fertility and hatchability of the hen's egg. Edinburgh: Oliver and Boyd, 1969, p.143-176.

MICHELS, H.; GEERS, R.; MUAMBI, S. The effect of incubation temperature on pre and post hatching development and chickens. British Poultry Science, v.15, p.517-523, 1974.

MORAES, T.G.V.; ROMAO, J.M.; TEIXEIRA, R.S.C. et al. Effects of egg position in artificial incubation of Japanese quail eggs (Coturnix japonica). Animal Reproduction, v.5, p.50-54, 2008.

MORAES, T.G.V.; ROMAO, J.M.; CARDOSO, W.M. Parâmetros da incubação e componentes dos ovos de codornas japonesas para corte (Coturnix japonica) submetidos à estocagem em baixas temperaturas (7,5 $\left.\pm 1^{\circ} \mathrm{C}\right)$. Semina: Ciências Agrárias, v.30, p.233-242, 2009.

ONO, H.; HOU, P.C.L.; TAZAWA, H. Responses of developing chicken embryos to acute changes in ambient temperature: Noninvasive study of heart rate. Israel Journal of Zoology, v.40, p.467-480, 1994.

PEDROSO, A.A.; CAFÉ, M.B.; LEANDRO, N.S.M. et al. Desenvolvimento embrionário e eclodibilidade de ovos de codornas armazenados por diferentes períodos e incubados em umidades e temperaturas distintas. Revista Brasileira de Zootecnia, v.35, p.2344-2349, 2006.

ROMANOFF, A.L. The influence of environment on early development. In: The Avian Embryo: Structural and Functional Development, New York: Macmillan, 1960, p.195-207.

ROMANOFF, A.L. Atmospheric changes. In: ROMANOFF, A.L. Pathogenesis of the avian embryo. An analysis of causes of malformations and prenatal death, vol. 4, New York: WileyInterscience, 1972, p.57-106.

ROMAO, J.M.; MORAES, T.G.V.; TEIXEIRA, R.S.C. et al. Effect of egg storage length on hatchability and weight loss in incubation of egg and meat type Japanese quails. Brazilian Journal of Poultry Science, v.10, p.143-147, 2008.

ROMAO, J.M.; MORAES, T.G.V.; TEIXEIRA, R.S.C. et al. Effect of relative humidity on incubation of Japanese quail eggs. Livestock Research for Rural Development, v.21, n.3, 2009.

ROMAO, J.M.; MORAES, T.G.V.; SILVA, E.E. et al. [2010]. Incubation of Japanese quails eggs stored at tropical temperatures. Livestock Research for Rural Development, v.22, n.1, 2010.

SMITH, K.P.; BOHREN, B.B. Age of pullet effect on hatching time, egg weight and hatchability. Poultry Science, v.54, p.959-963, 1975.

STATISTIX, 2003. Statistix for Windows Manual. Copyright ${ }^{\circledR}$ 1985-2003. Analytical Software. Version 8.0. 
SUAREZ, M.E.; WILSON, H.R.; MCPHERSON, B.N. et al. Low temperature effects on embryonic development and hatch time. Poultry Science, v.75, p.924-932, 1996.

TAZAWA, H.; WAKAYAMA, H.; TURNER, J.S. et al. Metabolic compensation for gradual cooling in developing chick embryos. Comparative

Biochemistry and Physiology, v.89, p.125-129, 1988.
WILSON, H.R. Physiological requirements of the developing embryo: Temperature and turning. In: TULLET, S.G. Avian Incubation, London:

Butterworth-Heinemann, 1991, pp 145-156. 